\title{
Two Sides of the Same Coin? The Differing Roles of Assets and Consumer Debt in Marriage
}

Jeffrey P. Dew

Brigham Young University - Provo, jeff_dew@byu.edu

Follow this and additional works at: https://scholarsarchive.byu.edu/facpub

Part of the Other Social and Behavioral Sciences Commons

\section{Original Publication Citation}

Dew, J. P. (2007). Two sides of the same coin? The differing roles of assets and consumer debt in marriage. Journal of Family and Economic Issues, 28, 89-104.

\section{BYU ScholarsArchive Citation}

Dew, Jeffrey P., "Two Sides of the Same Coin? The Differing Roles of Assets and Consumer Debt in Marriage" (2007). Faculty Publications. 4507.

https://scholarsarchive.byu.edu/facpub/4507 


\title{
Two Sides of the Same Coin? The Differing Roles of Assets and Consumer Debt in Marriage
}

\author{
Jeffrey Dew
}

Published online: 6 February 2007

(C) Springer Science+Business Media, LLC 2007

\begin{abstract}
This study examines whether assets and consumer debts relate to change in marital satisfaction and conflict in opposing ways or in independent ways. It also tests whether these relationships are direct or mediated. Using a nationally representative longitudinal sample, the results indicate that assets and consumer debt influence change in marital outcomes in mostly independent rather than complementary ways. Consistent with prior literature, assets work indirectly by decreasing feelings of economic pressure. Consumer debt, however, directly predicts changes in marital conflict, even after controlling for variables in the family stress model. Debts also act indirectly by decreasing depression once economic pressure is included in the model. This unexpected suppressor effect suggests that the meaning of debts may not be straightforward.
\end{abstract}

Keywords Assets $\cdot$ Conflict $\cdot$ Debts $\cdot$ Marriage $\cdot$ Satisfaction

\section{Introduction}

When saving behaviors and consumer debt use are considered, American's households are not in good financial health. For example, Americans saved less than $2 \%$ of their monthly income in 2004 (down from 10\% in 1980) (Baker, 2004; US Department of Commerce, 2005). Further, although Americans have higher levels of home equity than ever before, utilization of home equity loans is also the highest that it has ever been (Masnick, Di, \& Belsky, 2005). Consumer debt levels are also problematic. Outstanding consumer credit, credit that cannot be used to generate human or financial capital (e.g., credit card debt), rose 500 billion dollars between the years of 1999 and 2003 to a record total of over two trillion dollars (Federal Reserve Board, 2004). Perhaps more problematic for individual families is that the average

J. Dew $(\bowtie)$

Department of Human Development and Family Studies and Program of Demography, Pennsylvania State University, S-113 South Henderson Bldg, University Park, PA 16802, USA e-mail: jpd197@juno.com 
American household carries consumer debt equal to $20 \%$ of its income, also an alltime high (Maki, 2000). Given these trends, it is not surprising that nearly 13 million households filed for bankruptcy between 1996 and 2004 (US Courts, 1997, 1998, 2000, 2002, 2004). Although most married couples carry both assets and consumer debts, little is known about the relationship between these two financial issues and marital outcomes such as marital satisfaction or conflict.

The few studies that have examined this question have treated assets and debts in such a way that limits knowledge about their relationship with marital outcomes. First, most studies have combined assets and consumer debts mathematically (e.g., through debt-to-asset ratios), perhaps following the lead of common accounting practices. This strategy ignores the possibility that assets and debts may influence marital outcomes in completely different ways, rather than simply predicting the same outcomes with opposing signs. Although assets and debts are dollar for dollar complements on a balance sheet, each may have separate consequences for marriage.

A second problematic analytical strategy has been to test either the direct or the indirect relationships with debts and assets on marital outcomes, but never to test both simultaneously. Because direct and indirect relationships have never been tested simultaneously, it is unknown whether the relationship between assets, debts, and marital relationships are mediated (Conger, et al., 1993; Conger, Ge, \& Lorenz, 1994) or direct (Galligan \& Bahr, 1978; Schaninger \& Buss, 1986).

The final question about prior findings that link assets, debts, and marital outcomes is whether they generalize to the US population. Some studies used local samples that may have confounded the relationship between assets, debts, and marriage with local economic conditions (Shaninger \& Buss, 1986). Other studies of the effects of financial issues on marital outcomes were designed to understand the effects of the farm crisis of the early 1980s on rural families. Thus, many of the samples were composed of farm families and their rural neighbors (Murdock, Hamm, Potter, \& Albrecht, 1988; Conger et al., 1993, 1994).

Trying to generalize the results of studies on assets and debts from rural couples to nonrural couples is problematic because rural couples depend on their assets and the ability to obtain debt to generate income while most nonrural couples do not. For example, farm families hold assets in their land and farm equipment. Further, the ability to procure debt in order to support one's occupation and livelihood was essential in agricultural production during the 1970s agricultural expansion (Lasley, 1994), and this might still be the case.

Although many young professionals assume large amounts of student debt to finance their education (e.g., medical and law students), fundamental differences may exist between them and farm families. First, student debt begins to accrue interest only after students graduate - a time when these professionals begin to earn enough money to pay off their debt. Second, young professionals only incur student debt before their careers begin. After they begin their careers, their future livelihoods do not generally depend on being able to secure more debt.

Examining the way that assets and consumer debt relate to marital outcomes could lead to findings that would both inform theory and give practical guidance for couples. For example, if it is shown that assets and consumer debt relate to marital outcomes in a dissimilar manner, scholars may want to model them independently rather than combining them mathematically. If one financial concern (e.g., asset accumulation) relates to marital outcomes more closely than the other does, families 
may want to adjust their financial management strategy to favor that concern (e.g., by using income to accumulate assets quickly instead of quickly paying down consumer debt).

\section{Literature Review}

\section{The Family Stress Model}

The family stress model (see Fig. 1) has been one of the main models used to test the relationship between financial issues and marital outcomes. In the family stress model, financial difficulties predict feelings of economic pressure (Conger et al., 1990, 1993, 1994; Conger, Rueter, \& Elder, 1999). Economic pressure is a state of distress brought about by worry over one's finances, having to cut back in consumption, and becoming dissatisfied with one's finances. Negative financial events, such as job loss, and individual financial behaviors predict economic pressure (Conger et al., 1990, 1994; Vinokur, Price, \& Caplan, 1996; Joo \& Grable, 2004). Economic pressure increases emotional distress, which in turn increases conflictive marital interactions and decreases positive marital interactions (Conger et al., 1990, 1993, 1994, 1999).

When tests of the family stress model have included assets and debts, they have always used debt-to-asset ratios. As noted above, this is conceptually problematic because consumer debt and assets may relate to marital outcomes differentially rather than complementarily. Further, a debt-to-asset ratio of zero says nothing about a couple's assets. Individuals with no debt may have no assets, or they may

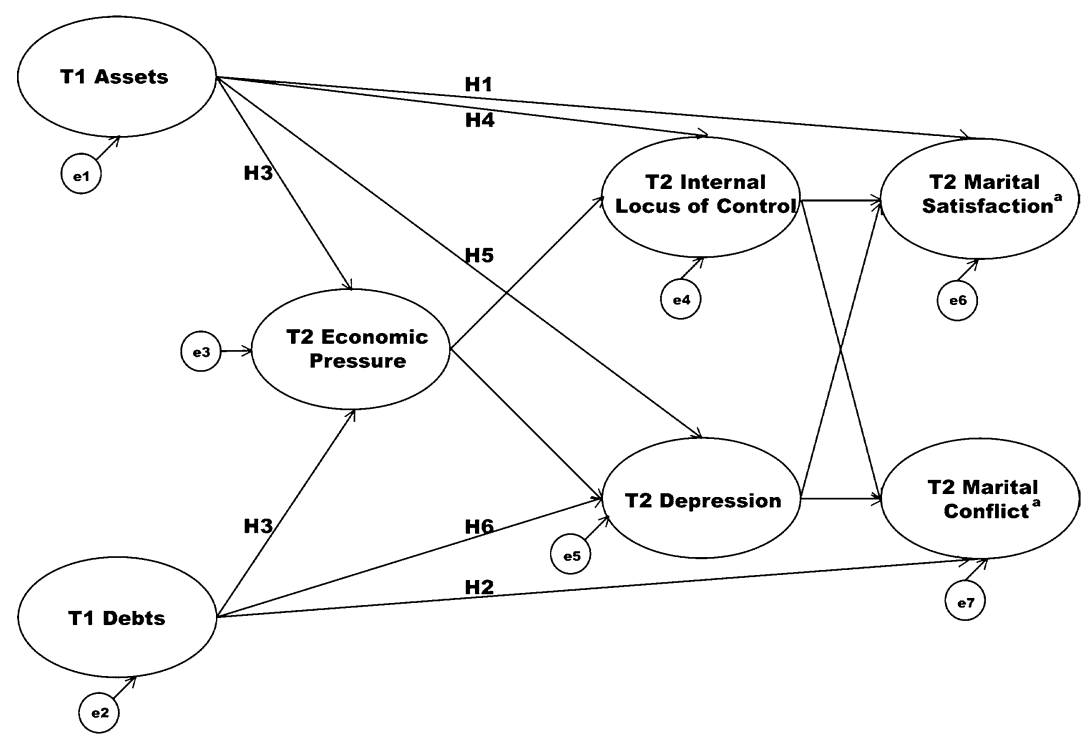

Fig. 1 Hypothesized indirect and direct relationships of assets and consumer debt in the family stress model.

Note: See Table 3 for measurement model. Control variables not shown. T1 time one, T2 time two, $H$ Hypothesis, E Error

${ }^{\mathrm{a}} \mathrm{T1}$ Levels of construct controlled 
hold millions of dollars in assets. However, both extremes have a debt-to-asset ratio of zero.

An additional concern is that tests of the family stress model have limited assets and consumer debts to predicting feelings of economic pressure. This conflicts with research that has shown a direct relationship between assets and marital satisfaction (Schaninger \& Buss, 1986) and studies that have demonstrated that consumer debt relates to anxiety even after the financial stress it causes is accounted for (Drentea, 2000). Despite these issues with tests of the family stress model, the model itself provides an ideal framework to test whether assets and debts relate to marital outcomes independently or in complementary ways, and whether these relationships are indirect or direct. The family stress model is ideal because it is an empirically validated model that includes financial concerns, marital outcomes, and the variables that mediate the influence of financial concerns on marital outcomes. These elements are all necessary for evaluating the research questions in this study.

\section{Are Assets and Consumer Debts Complements in Marriage?}

Assets and debts may carry fundamentally different meanings for married couples. Although the economic necessity of marriage declined in the 20th century, asset accumulation is still very much a part of the contemporary marital script. Having children, owning a home, funding children's education, maintaining a comfortable retirement, etc., are all ideals that society expects married individuals-especially husbands-to work toward (Townsend, 2002). Attaining these cultural ideals is expensive, often requiring decades of financial inputs as couples acquire assets. Thus, social norms regarding marriage incorporate asset accumulation. Further, jointly held assets may represent what spouses both desire and consequently may be an investment in the marriage (Levinger, 1976).

Married couples seem to follow these social norms of asset accumulation. Although structural barriers to asset accumulation do exist (White \& Rogers, 2000; Hirschl, Altobelli, \& Rank, 2003), married couples save at higher rates than other types of families even after controlling for income, education, and other selection variables (Waite, 1995; Carney \& Gale, 2001; Lupton \& Smith, 2003). In addition, the longer spouses stay married, the more wealth they accumulate (Hao, 1996; Lupton \& Smith, 2003).

Although ethnographic research has linked asset accumulation to social norms related to marriage and parenthood, sociological and economic research has shown that asset accumulation serves financial purposes. Assets may be used to support daily consumption needs, to facilitate financial security, or to increase financial capital (Xiao, 1996; Xiao \& Anderson, 1997; Beverly, McBride, \& Schreiner, 2003). If assets serve financial rather than normative purposes, then assets should only indirectly influence marriage by decreasing feelings of economic pressure.

If, however, asset accumulation within marriage is related to social norms, married couples who accumulate assets are performing their marital roles according to social expectations. According to identity theory, when individuals feel they are successfully performing their role, they experience increased satisfaction with and commitment to the specific role (Ervin \& Stryker, 2001). Consequently, as couples successfully perform marital roles (by accumulating assets) their marital satisfaction 
should increase. This suggests that assets may have a more direct role in marital outcomes than past tests of the family stress model have indicated.

Hypothesis 1 (H1) Despite controlling for mediating processes, assets positively predict a change in marital satisfaction (see Fig. 1).

In contrast to assets, very little theory exists about the relationship between consumer debt and marital outcomes. Although scholars have noted the relationship between debt and marital strain in retrospective reports (Murdock et al., 1988), research has not articulated the theory behind this relationship. Even though couples may use consumer debt to meet specific financial goals that relate to different periods in the life course (Baek \& Hong, 2004), consumer debt is certainly not as much a part of the marital script as asset accumulation.

In general, consumer debt may represent a loss of choice. One's financial future becomes written when large amounts of consumer debt are assumed (Elder, Robertson, \& Foster, 1994). Additionally, studies have found that individuals work more hours than they desire so they can make consumer debt payments (Schor, 1998; Clarkberg \& Moen, 2001). Thus, consumer debt demands couples' future time and money, both highly valued commodities in our society.

Because consumer debt leads to less choice, spouses may argue about the desirability, necessity, and practicality of assuming debt. These disagreements or arguments may strain marriages independent of the emotional strain that being in debt creates, especially if one spouse assumes the debt despite the objection of the other. When a spouse feels that his/her partner handles money foolishly the odds of divorce increase substantially (Amato \& Rogers, 1997). Further, continued resentment over debt is also possible because the negative emotional effects of debt often remain long past the initial purchase as individuals continue to service their debt (Prelec \& Loewenstein, 1998). Additionally, if a couple has to limit purchases in order to serve their debt, this may increase marital tension (Conger et al., 1999). Consequently, consumer debt may increase the overall amount of marital conflict that couples experience. As with assets in hypothesis 1, this hypothesis expands the role of consumer debt in the family stress model.

Hypothesis 2 (H2) Despite controlling for mediating processes, consumer debt positively predicts change in the frequency of conflict that couples experience (see Fig. 1).

This hypothesis conflicts with a purely economic rational choice model. In a rational choice model, the assumption of consumer debt is a voluntary action undertaken by rational actors to maximize individual and couple utility. Consequently, an action undertaken to maximize utility should not have adverse effects.

Two reasons may explain why the assumption of consumer debt may have adverse consequences on marital outcomes even in light of rational choice. First, the marketers of consumer credit often hide its true financial burden (Peterson, 2004). Thus, individuals might come to understand the full financial consequences of their decision only after assuming and servicing the debt. Second, the utility of purchases can fall as individuals continue to service their debt (Prelec \& Loewenstein, 1998). Consequently, even though individuals may be voluntarily expanding their debt, under the assumption that it will maximize their utility, they might be underestimating or ignoring the long-term consequences of consumer debt assumption.

Hypotheses 1 and 2 suggest that debts and assets are not simply economic opposites when marital outcomes are concerned, but rather influence marital outcomes in different ways. The hypotheses suggest that assets directly relate to marital 
satisfaction because of social norms and that consumer debts predict marital conflict because they force couples to expend time and money.

\section{The Indirect Influences of Assets and Debts on Marital Outcomes}

As the dissimilarities between assets and debts were considered, possible direct relationships between the assets, debts, and marital outcomes arose. The indirect relationships in the family stress model may allow assets and debts to act in a complementary manner. Debt-to-asset ratios have predicted couples' economic pressure (Conger et al., 1993, 1994); therefore, the present study should also find that assets and consumer debt predict economic pressure. However, the test in this study is slightly different from previous tests because assets and consumer debts will not be mathematically combined. Consequently, assets and consumer debt should predict economic pressure in opposite directions.

Hypothesis 3 (H3) Assets and consumer debts predict economic pressure in opposite directions.

Beyond influencing economic pressure, assets may also predict spouses' feelings of control. As couples make the decision to set aside resources for future use, they feel more in control of their lives (Yadama \& Sherraden, 1996). Locus of control has not been included in prior tests of the family stress model. However, this study includes locus of control because it is a variable that relates to assets and may, therefore, go on to predict marital satisfaction and conflict.

Hypothesis 4 (H4) Despite controlling for the effect of feelings of economic pressure, assets indirectly predict marital conflict by altering husbands' and wives' internal locus of control.

Related to locus of control, depression might decrease as couples accumulate assets. Epidemiologists have demonstrated that wealth is associated with lower prevalence rates of mood and anxiety disorders (Muntaner, Eaton, Diala, Kessler, \& Sorlie, 1998). They argue that assets have a salutary effect on mental health because they decrease economic pressure.

However, the model in Fig. 1 shows that assets should decrease depression even after controlling for economic pressure. Scholars have found that assets offer individuals more life opportunities and choices (Sherradan, 1991; Caputo, 2003). By expanding opportunities, assets may decrease depression, independent of their effect on economic pressure.

Hypothesis 5 (H5) Despite controlling for feelings of economic pressure, assets indirectly relate to marital satisfaction by decreasing husbands' and wives' depression.

Debts may also predict depression, but in an opposing manner to assets. Although research has never examined the relationship between consumer debt and depression per se, consumer debt is known to predict a psychological state related to depression-anxiety. Drentea (2000) found that debt-to-income ratios were positively associated with anxiety. When the stress about the debt itself was considered, the relationship between anxiety and debt-to-income ratios was reduced, but not below significance. Thus, debts may increase psychological distress beyond the economic pressure they generate.

Hypothesis 6 (H6) Despite controlling for feelings of economic pressure, consumer debts indirectly relate to marital conflict by increasing husbands' and wives' depression. 
Considering Fig. 1 as a whole, then, this study models both the indirect and direct effects of assets and debts on marital outcomes. For the direct effects, assets, and consumer debts are hypothesized to predict different marital outcomes rather than predicting the same outcome in an opposite manner. For the indirect effects, assets, and debts likely play complementary roles by relating to both economic pressure and depression in opposing directions.

\section{Method}

Data and Sample

This study used data from the first two panels of the National Study of Families and Households (NSFH). Begun in 1987, the NSFH is a nationally representative longitudinal study of individuals. It began with 13,007 individuals and surveyed many of the participants' partners. This study used a sample of all individuals who were married in the first panel and remained married through the second. These requirements yielded a sample of 3,731 participants.

The sample was restricted to married individuals for four reasons. First, married individuals are more likely than cohabiting individuals to pool income and assets (Heimdal \& Houseknecht, 2003; Fletschner \& Klawitter, 2005). Second, marriage enjoys a unique legal stance in that it enables couples to hold assets and debts jointly. Relatedly, undertaking legal proceedings to end the marital relationships often means dividing assets and debt. Third, married individuals generally accumulate more assets over their lives than nonmarried individuals (Hirschl et al., 2003). Finally, cohabiting relationships are more unstable than marriage, with $90 \%$ of cohabiting unions ending within 5 years (Bumpass \& Lu, 2000). Since 4-7 years separated the first and second panels of the NSFH, it would have been almost impossible to use this data to study the role of assets and debts in cohabiting unions.

\section{Analysis}

Structural equation modeling was used to test all the hypotheses. Outcome variables were regressed onto theoretically antecedent variables according to the family stress model. That is, marital conflict and marital satisfaction were regressed onto measures of psychological well being (depression and locus of control) (Conger et al., 1994, 1999). Depression and locus of control were regressed onto economic pressure. In addition to the paths specified by the family stress model, time one (T1) assets were modeled to predict depression, locus of control, and marital satisfaction. Also, T1 consumer debts were modeled to predict depression and marital conflict. Time two (T2) marital conflict was regressed onto T1 marital conflict, like other studies using the family stress model. T2 marital satisfaction was also regressed onto T1 marital satisfaction.

The analyses also investigated an alternate model. In this model, assets and debts predicted every outcome variable, not just the hypothesized outcomes variables. The reasoning behind this model was that if assets really did act differently than consumer debts, assets should not be a significant predictor of marital conflict and debts should not be able to predict marital satisfaction. Further, consumer debt should be unrelated to locus of control. 


\section{Measures}

The NSFH data has detailed questions on ownership and values of different types of assets. This study used T1 net asset values of three asset types: savings, investments, and home equity. The log transformation (base 10) of each asset type was used to correct for the skewness of the distributions. Because many demographic characteristics (e.g., race, age) have been shown to predict asset accumulation (Xiao, 1996; White \& Rogers, 2000; Hirschl et al., 2003), assets were modeled endogenously instead of exogenously. That is, the T1 control covariates predicted T1 assets rather than correlating with them.

This study used total consumer debt, instead of total debt, because consumer debt may relate differently to marriage than nonconsumer debt. Couples can use nonconsumer debt to generate human and financial capital (Ferber \& Lee, 1980). Additionally, consumer debt generally carries a much higher interest rate than nonconsumer debt (Drentea, 2000; Maki, 2000; Baek \& Hong, 2004; Peterson, 2004). Finally, collection practices for consumer debt are much more aggressive than for nonconsumer debt (Peterson, 2004). This research used three T1 indicators of consumer debt: credit card debt, installment loans on consumer goods, and past-due bills. To correct the positive skew of debts the log transformation (base 10) was used for each debt type. Like assets, debts were modeled endogenously because many of the same demographic variables that influence asset accumulation also predict the likelihood of obtaining consumer credit (Crook, 2001; Baek \& Hong, 2004).

The latent construct of economic pressure had two indicator variables. One item asked participants how often they worry about being able to pay their bills. It ranged from 1 (Almost all the time) to 5 (Never). The other variable asked respondents to rate their satisfaction with their finances. It ranged from 1 (Very dissatisfied) to 7 (Very satisfied). These variables were reverse coded so that the higher the score, the more economic pressure they feel.

Depression had 12 indicators taken from the CES-D (Radloff, 1977). These items asked participants to indicate how many days they felt certain symptoms of depression such as not feeling like eating or feeling depressed.

Locus of control had three indicator variables. These were three items from the Pearlin Mastery Scale that measure to what extent individuals feel they are controlled by outside forces in their lives (Pearlin \& Schooler, 1978).

Four items indicated marital conflict. Respondents reported how often they disagree about four different marital dimensions: time together, household tasks, sex, and in-law relations.

A global marital satisfaction item measured marital satisfaction. Although a multi-dimensional marital satisfaction scale was more desirable than a global item, one was not included until the second wave. This may not be a problem, however, because research using a single global marital satisfaction item can yield just as valid and robust findings as multi-dimensional scales if sample sizes are large enough (Johnson, 1993).

The control covariates were (a) age, (b) education, (c) income, (d) marital duration, (e) number of children, (f) the number of marriage they were currently in, (g) gender, and (h) whether participants are NonHispanic White. Research has shown that these variables relate to the likelihood of asset ownership, to the amount of assets and debts individuals have, and to marital outcomes (Mirowsky \& Ross, 
1999; White \& Rogers, 2000; Crook, 2001; Baek \& Hong, 2004; Hogarth, Anguelov, \& Lee, 2005).

\section{Results}

Descriptive and Bivariate Results

Descriptive results demonstrated the high-debt/low-savings profile typical of American families (Schor, 1998; Federal Reserve Board, 2004, see Table 1). Sixty percent of the participant families reported some sort of consumer debt. Those who held credit card debt (nearly $50 \%$ of the sample) had a median $\$ 1,000$ in credit card debt and $\$ 800$ in installment debt. The median amount of savings was only $\$ 4,000$, and the median net home equity was $\$ 35,000$. Those with investments (only $39 \%$ of the sample) held a median $\$ 4,000$. All results are in 1988 dollars.

Although the debt levels seemed low compared to current statistics in government reports and the popular press, they are comparable to other surveys taken in the late 1980s. Indebtedness patterns and levels in this sample were quite similar to those reported in the 1989 Survey of Consumer Finances (Kennickell \& StarrMcCluer, 1994). One of the reasons these numbers seem somewhat below expectations is that consumer debt levels rose extremely quickly during the 1990s (Schor, 1998; Federal Reserve Board, 2004).

Bivariate correlations of observed variables offered some support for the hypotheses (see Table 2). Assets were negatively correlated with economic pressure $(r=-0.19, p<0.001)$ and depression $(r=-0.09, p<0.001)$. They were positively correlated with an internal locus of control $(r=0.08, p<0.001)$. Contrary to

Table 1 Descriptive statistics

\begin{tabular}{|c|c|c|c|}
\hline Asset type & $\begin{array}{l}\text { Financial assets } \\
\text { Median for asset holders }\end{array}$ & Reporting type (\%) & Range \\
\hline $\begin{array}{l}\text { Savings } \\
\text { Housing Equity } \\
\text { Investments }\end{array}$ & $\begin{array}{l}\$ 4,000 \\
\$ 35,000 \\
\$ 4,000\end{array}$ & $\begin{array}{l}74 \\
63 \\
39\end{array}$ & $\begin{array}{l}0-150,000 \\
0-996,000 \\
0-150,000\end{array}$ \\
\hline Debt type & $\begin{array}{l}\text { Consumer debts } \\
\text { Median for debt holders }\end{array}$ & Reporting type (\%) & Range \\
\hline $\begin{array}{l}\text { Credit card debt } \\
\text { Installment debt } \\
\text { Past due bills }\end{array}$ & $\begin{array}{l}\$ 1,000 \\
\$ 800 \\
\$ 524\end{array}$ & $\begin{array}{l}48 \\
16 \\
12\end{array}$ & $\begin{array}{l}0-42,000 \\
0-25,000 \\
0-96,000\end{array}$ \\
\hline \multicolumn{3}{|c|}{ Demographic characteristics } & Range \\
\hline $\begin{array}{l}\text { Age } \\
\text { Education } \\
\text { Income } \\
\text { Marital Duration } \\
\text { Number of children } \\
\text { Number of marriages } \\
\text { Gender } \\
\text { Race }\end{array}$ & $\begin{array}{l}36.7 \\
13.1 \\
\$ 32,516^{\mathrm{a}} \\
11.1 \\
1.39 \\
1.24 \\
56 \% \text { Women, } 44 \% \text { Men } \\
82 \% \text { Nonhispanic white, } 18 \% \text { Other }\end{array}$ & & $\begin{array}{l}18-59 \\
0-20 \\
0-982,000 \\
0-40 \\
0-11 \\
1-5\end{array}$ \\
\hline
\end{tabular}

\footnotetext{
a Sample median
} 
Table 2 Pearson correlations between assets, debts, and variables in the family stress model

\begin{tabular}{lcccccc}
\hline & 1 & 2 & 3 & 4 & 5 & 6 \\
\hline 1 T1 Assets & & & & & & \\
2 T1 Debts & -0.01 & & & & & \\
3 T2 Economic pressure & $-0.19^{* * *}$ & $0.09^{* * *}$ & & & & \\
4 T2 Depression & $-0.09^{* * *}$ & 0.03 & $0.33^{* * *}$ & & & \\
5 T2 Internal locus of control & $0.08^{* * *}$ & -0.01 & $-0.27^{* * *}$ & $-0.36^{* * *}$ & & \\
6 T2 Marital conflict & $0.10^{* * *}$ & $0.05^{* *}$ & $0.23^{* * *}$ & $0.31^{* * *}$ & $-0.18^{* * *}$ & \\
7 T2 Marital Satisfaction & -0.01 & -0.03 & $-0.19^{* * *}$ & $-0.26^{* * *}$ & $-0.17^{* * *}$ & $-0.31^{* * *}$ \\
\hline
\end{tabular}

$T 1$ time one, $T 2$ time two

$* p<0.05$

$* * p<0.01$

$* * * p<0.001$

hypothesis 1 , however, assets did not correlate with marital satisfaction. Debts were positively related to economic pressure $(r=0.09, p<0.001)$, and marital conflict $(r=0.05, p<0.01)$, but did not predict depression.

\section{Structural Equation Results}

Unlike the bivariate relationships, the structural equation model showed limited support for the hypotheses (see Fig. 2 for structural model, Table 3 for measurement model). Fit statistics appropriate for large sample sizes indicated that the model fits the data well $(C F I=0.95, R M S E A=0.03)$. Consistent with prior literature, assets,

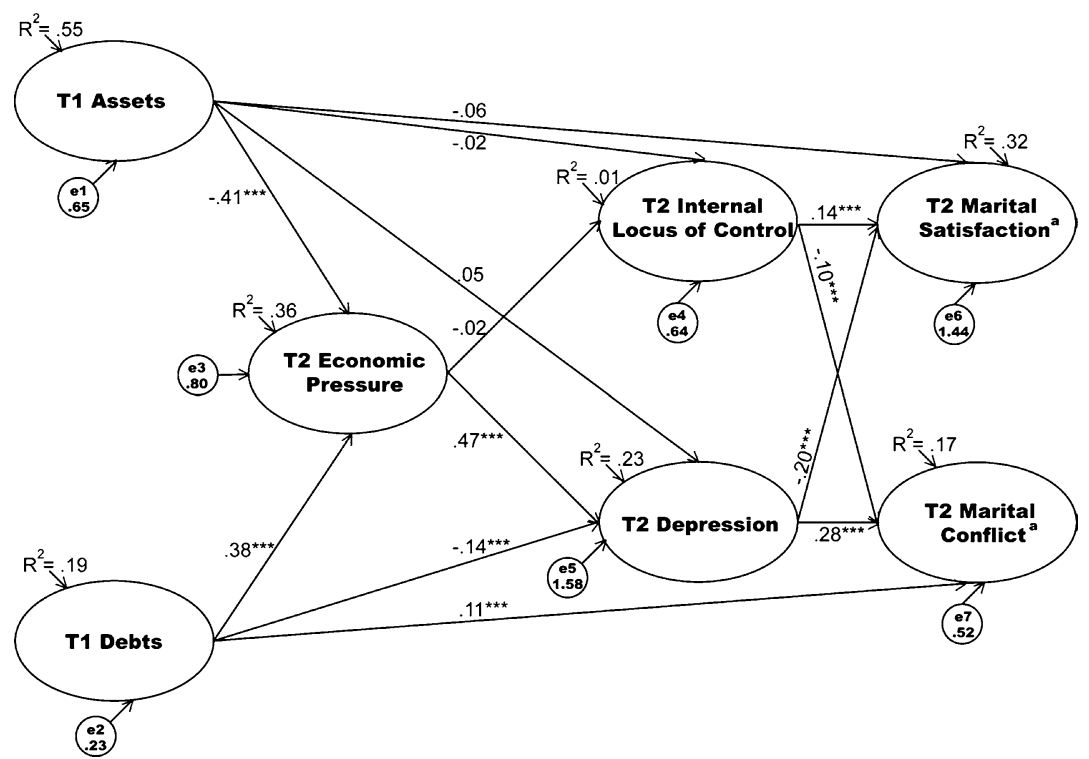

Fig. 2 Structural model of the relationships of assets and consumer debts in the family stress model. $\chi^{2}(691, N=3,731)=3,216, p<0.001, C F I=0.95 R M S E A=0.03$. Control variables not shown. Standardized path coefficients. $T 1$ time one, $T 2$ time two, $E$ Error ${ }^{\mathrm{a}} T 1$ Levels of construct controlled, $* p<0.05, * * p<0.01, * * * p<0.001$ 
Table 3 Measurement model of the effects of assets and consumer debts in the family stress model

\begin{tabular}{lll}
\hline Latent variable & Indicator & Loading \\
\hline T1 Assets & T1 Savings & $0.74^{\mathrm{a}}$ \\
& T1 Investments & $0.59^{* * *}$ \\
& T1 Home equity & $0.51^{* * *}$ \\
T1 Debts & T1 Credit card debt & $0.34^{\mathrm{a}}$ \\
& T1 Installment loan debt & $0.31^{* * *}$ \\
T2 Economic pressure & T1 Past due bills & $0.27^{* * *}$ \\
& T2 Worry over finances & $0.82^{\mathrm{a}}$ \\
T2 Internal locus of control & T2 Satisfaction with finances & $0.72^{* * *}$ \\
T2 Depression & T2 three Items from the pearlin mastery scale & $0.58^{* * *}-0.71^{\mathrm{a}}$ \\
T2 Marital conflict & T2 12 Items from the CES-D & $0.62^{* * *}-0.87^{\mathrm{a}}$ \\
& How often couples argue about: & $0.73^{\mathrm{a}}$ \\
& T2 Time together & $0.55^{* * *}$ \\
& T2 Dividing household chores & $0.68^{* * *}$ \\
& T2 Sex & $0.44^{* * *}$ \\
\hline
\end{tabular}

Standardized indicator loadings, $T 1$ time one, $T 2$ time two

${ }^{a}$ Fixed indicator

$* p<0.05$

$* * p<0.01$

$* * * p<0.001$

and debts significantly predict economic pressure $(\beta=-0.41 p<0.001 ; \beta=0.38$ $p<0.001$, respectively) - though this study treats them as separate constructs, rather than mathematically combining them.

Except for negatively predicting economic pressure, assets had no indirect or direct effects on marriage (see Fig. 2). Assets predicted neither an internal locus of control nor depression. They were also unrelated to marital satisfaction. Thus, hypotheses 1,3 , and 4 were not supported.

Consistent with hypothesis 2 , debts positively predicted changes in marital conflict $(\beta=0.11, p<0.001)$. This direct relationship remained even after taking the mediating variables of the family stress model into account.

Contrary to hypothesis 5 , however, debts negatively predicted depression $(\beta=-$ $0.14, p<0.001)$. A negative relationship was unexpected especially since debts and depression were unrelated in the bivariate correlations, and theory predicted a positive relationship. Tests of collinearity between consumer debt and other variables yielded no suspect relationships. When the structural equation model was run without economic pressure (not shown), debts are unrelated to depression. This may indicate that once the main effect of economic pressure on depression is accounted for (e.g., increasing depression), a new aspect of debts emerges. Despite the emergence of this counterintuitive finding, using path tracing rules it can be shown that the indirect effect of debt on marital conflict through depression $(-0.04)$, is smaller than the indirect effect of debt on marital conflict that goes from debt, through economic pressure, and then depression (0.05), and is much smaller than the direct effect of debt on marital conflict (0.11).

The alternative model offered support for the view that assets and consumer debts play different roles in marriage. Assets did not predict marital distress though debt continued to do so (not shown). Further, debts predicted neither marital satisfaction nor locus of control. 


\section{Discussion}

This study seeks to fill three existing gaps in the literature by examining whether assets and consumer debts relate to marital outcomes in complementary ways or in independent ways, whether these relationships are direct or indirect, and whether these relationships could be found in a national sample. Findings reveal that except for predicting economic pressure, assets, and consumer debts are not simply polar economic forces in marriage; rather they relate to marriage in completely different ways. Second, this study finds that consistent with prior research (Conger et al., 1993, 1994), assets have only an indirect relationship with marital outcomes. Contrary to prior research, however, consumer debts relate directly to marital outcomes regardless of the mediating variables of the family stress model. This study also indicates that relationships between assets, consumer debts, and marital outcomes do exist for married American couples, and not just for rural families.

The differing relationships between assets, consumer debt, and marital outcomes suggest that these two financial variables are not simply opposites on a spreadsheet when relationships are considered. Rather, assets and consumer debts mean different things for marriage. Consistent with prior literature (Conger et al., 1993, 1994), assets perform the important function of reducing feelings of economic pressure. Because assets do not directly relate to marriage, it is doubtful that asset accumulation serves a normative purpose in marriage, as suggested in ethnographic studies (Townsend, 2002). Rather, assets seem to reduce economic worries as suggested in sociological and economic studies (Conger et al., 1993, 1994; Xiao, 1996; Xiao \& Anderson, 1997; Beverly et al., 2003). Because spouses tend to accumulate more assets the longer they stay married, the indirect positive effect of assets may increase over time (Hao, 1996; Mirowsky \& Ross, 1999).

Like assets, consumer debt predicts economic pressure; unlike assets, however, it also directly relates to marital outcomes. Consumer debt measured at time one predicts changes toward more frequent marital conflict. This relationship may reflect couples' recognition that consumer debt limits future choices. Couples may resent the time and money required to service a debt, especially if one spouse assumed a debt without the input of, or in spite the objections of, the other. Additionally, debt may serve as a point of conflict by itself, which may increase the frequency of conflict in other domains. That debt predicts conflict 5 years out even after controlling for initial conflict indicates that consumer debt's role in marital distress is robust.

Surprisingly, debts also seem to slightly help marriages indirectly by decreasing depression. The results point to a suppressor effect of economic pressure on the relationship between debt and depression. Normally, a mediating variable accounts for the variance in the outcome variable that was associated with the independent variable and thus reduces the relationship between the two original variables to zero. With suppressor effects, however, a mediating variable accounts for the primary relationship between the independent variable and the dependent variable. When the primary relationship is accounted for, another relationship between the two variables emerges that may be in the opposite direction. That is, the independent variable has two different sides and one side masks the other.

In support of a suppressor interpretation, debts demonstrate no relationship with depression until economic pressure is added to the model. When the variance associated with economic pressure is removed from depression, consumer debt 
positively predicts it. With suppressor effects, the task becomes uncovering the dual nature of the independent variable that brings about the opposing relationship with the dependent variable when the mediator is added.

Once the model accounts for feelings of economic pressure, debt may decrease depression because of social comparison. Feelings of wellbeing covary with judgments of an individual's financial situation relative to others (Smith, Diener, \& Wedell, 1989; Hagerty, 2000). Some individuals may use credit to "keep up with the Joneses" (Schor, 1998), and consequently enhance their feelings of well-being. Since the emotional cost of this strategy (e.g., feelings of economic pressure) is partialled out of depression in the model, what might be left is the positive well-being individuals get from using debt to consume at levels that are equal to (or that exceed) their own reference group.

Because consumer debt relates more closely to marital outcomes than assets do, this study suggests that married couples would be better off paying down consumer debt as quickly as they can rather than trying to accumulate assets at the same time. Paying down or avoiding consumer debt is one of the mainstays of consumer education. The programs usually focus on the positive economic consequences of paying off and avoiding debt. This study gives couples relationship reasons to do so as well. That is, paying down consumer debt may directly reduce the amount of marital tensions that couples experience instead of just reducing feelings of economic pressure.

This study is not without limitations. A main limitation is that the participants report many of the outcomes at the same time. Although the model was constructed using theory and prior findings (Conger et al., 1993, 1994, 1999) and though modeling reverse relationships (e.g., regressing depression and locus of control on marital conflict) did not improve the fit of the model, the findings should be treated with some caution.

Another limitation in this study is the 4-7 years between the panels. Much activity in asset and debt levels, financial events, and marriage processes takes place in 5 years. However, these panels are too far apart to capture this complexity. Researchers might improve studies involving finances and marriage if they capture independent variables, processes, and outcomes within months or even weeks of each other.

Despite the limitations of this study, the findings offer directions for future research. First, these findings suggest that researchers should model assets and consumer debt in ways that allow them to exert independent effects. If this study had combined assets and debts in a debt-to-asset ratio, the finding that debt influences marital conflict, but that assets do not, would not have emerged. In addition, allowing assets and debts to remain separate brought out the dual nature of debts. Since assets and debts can work independently, rather than just complementarily, future research should continue experimenting with different methods of measuring and modeling the independent and joint effects of assets and debts.

The mechanism through which consumer debt brings about more arguments is unknown. Relatedly, theory on debt is underdeveloped. Few scholars have studied the psychosocial consequences of debt, let alone the mechanisms that bring about these consequences. With the notable exception of Prelec and Loewenstein (1998), no one has studied exactly how people think about their debt. Marital scholars might successfully employ qualitative methods to understand the process individuals go through as they decide to assume debt, make their purchase, and then service their debt. 
Acknowledgments The author would like to thank David Eggebeen, Chalandra Bryant, and two anonymous reviewers for their comments on a previous draft. A portion of this study was presented as a poster at the 2005 annual conference of the Population Association of America.

\section{References}

Amato, P. R., \& Rogers, S. J. (1997). A longitudinal study of marital problems and subsequent divorce. Journal of Marriage and the Family, 59, 612-624.

Baek, E., \& Hong, G.-S. (2004). Effects of family life-cycle stages on consumer debts. Journal of Family and Economic Issues, 25, 359-385.

Baker, D. (2004). Dangerous trends: The growth of debt in the US economy. Retrieved from the Center for Economic and Policy Research Web site: http://www.cepr.net/publications/debt_trends.htm. Accessed 3 August 2005.

Beverly, S. G., McBride, A. M., \& Schreiner, M. (2003). A framework of asset-accumulation stages and strategies. Journal of Family and Economic Issues, 24, 143-156.

Bumpass, L., \& Lu, H. H. (2000). Trends in cohabitation and implications for children's family contexts in the United States. Population Studies, 54, 29-41.

Caputo, R. K. (2003). Assets and economic mobility in a youth cohort, 1985-1997. Families in Society, 84, 51-62.

Carney, S., \& Gale, W. G. (2001). Asset accumulation among low-income households. In T. M. Shapiro, \& E. N. Wolff (Eds.), Assets for the poor: The benefits of spreading asset ownership (pp. 165-205). New York: Russell Sage.

Clarkberg, M., \& Moen, P. (2001). Understanding the time-squeeze: Married couples' preferred and actual work-hour strategies. American Behavioral Scientist, 44, 1115-1135.

Conger, R. D., Elder, G. H. Jr., Lorenz, F. O., Conger, K. J., Simons, R. L., \& Whitbeck, L. B. (1990). Linking economic hardship to marital quality and instability. Journal of Marriage and the Family, 52, 643-656.

Conger, R. D., Conger, K. J., Elder, G. H. Jr., Lorenz, F. O., Simons, R. L., \& Whitbeck, L. B. (1993). Family economic stress and adjustment of early adolescent girls. Developmental Psychology, 29, 206-219.

Conger, R. D., Ge, X. J., \& Lorenz, F. O. (1994). Economic stress and marital relations. In R. D. Conger, \& G. H. Elder, Jr. (Eds.), Families in troubled times (pp. 187-203). New York: Aldine de Gruyter.

Conger, R. D., Rueter, M. A., \& Elder, G. H. Jr. (1999). Couple resilience to economic pressure. Journal of Personality and Social Psychology, 76, 54-71.

Crook, J. (2001). The demand for household debt in the USA: Evidence from the 1995 survey of consumer finance. Applied Financial Economics, 11, 83-91.

Drentea, P. (2000). Age, debt, and anxiety. Journal of Health and Social Behavior, 41, 437-450.

Elder, G. H. Jr., Robertson, E. B., \& Foster, E. M. (1994). Survival, loss, and adaptation: A perspective on farm families. In R. D. Conger, \& G. H. Elder, Jr. (Eds.), Families in troubled times (pp. 105-126). New York: Aldine de Gruyter.

Ervin, L. H., \& Stryker, S. (2001). Theorizing the relationship between self-esteem and identity. In T. J. Owens, S. Stryker, \& N. Goodman (Eds.), Extending self-esteem theory and research (pp. 29 55). New York: Cambridge University Press.

Federal Reserve Board (20046). Consumer credit: December 2003. Federal reserve statistical release. Retrieved from http://www.federalreserve.gov/releases/g19/20040206/. Accessed 16 February 2004.

Ferber, R., \& Lee, L. C. (1980). Asset accumulation in early married life. The Journal of Finance, 35, 1173-1188.

Fletschner, D., \& Klawitter, M. (2005). Yours, mine, and ours: How married couples hold their savings. Paper presented at the meeting of the Association for Public Policy Analysis and Management, Washington, DC.

Galligan, R. J., \& Bahr, S. J. (1978). Economic well-being and marital stability: Implications for income maintenance programs. Journal of Marriage and the Family, 40, 283-290.

Hagerty, M. R. (2000). Social comparisons of income in one;s community: Evidence from national surveys of income and happiness. Journal of Personality and Social Psychology, 78, 764-771. 
Hao, L. (1996). Family structure, private transfers, and the economic well-being of families with children. Social Forces, 75, 269-292.

Heimdal, K. R., \& Houseknecht, S. K. (2003). Cohabiting and married couples' income organization: Approaches in Sweden and in the United States. Journal of Marriage and Family, 65, 525-538.

Hirschl, T. A., Altobelli, J., \& Rank, M. R. (2003). Does marriage increase the odds of affluence? Exploring the life course probabilities. Journal of Marriage and Family, 65, 927-938.

Hogarth, J. M., Anguelov, C. E., \& Lee, J. (2005). Who has a bank account? Exploring changes over time, 1989-2001. Journal of Family and Economic Issues, 26, 7-29.

Johnson, D. R. (1993). Are single-item measures of marital quality valid? The case of marital happiness. Paper presented at the meeting of the National Council on Family Relations, Baltimore, MD.

Joo, S.-H., \& Grable, J. E. (2004). An exploratory framework of the determinants of financial satisfaction. Journal of Family and Economic Issues, 25, 25-50.

Kennickell, A., \& Starr-McCluer, M. (1994). Changes in family finances from 1989-1992: Evidence from the survey of consumer finances. Federal Reserve Bulliten, 80, 861-882.

Lasley, P. (1994). Rural economic and social trends. In R. D. Conger, \& G. H. Elder, Jr. (Eds.), Families in troubled times (pp. 57-78). New York: Aldine de Gruyter.

Levinger, G. (1976). A socio-psychological perspective on marital dissolution. Journal of Social Issues, 32, 21-47.

Lupton, J. P., \& Smith, J. P. (2003). Marriage, assets, and savings. In S. A. Grossbard-Shechtman (Eds.), Marriage and the economy (pp. 129-151). Cambridge, MA: Cambridge University Press.

Maki, D. M. (2000). The growth of consumer credit and the household debt service burden. Retrieved from Federal Reserve Board's Finance and Economic Discussion Series Web site from http:// www.federalreserve.gov/pubs/feds/2000/200012/200012pap.pdf. Accessed 1 April 2004.

Masnick, G. S., Di, Z. X., \& Belsky, E. S. (2005). Emerging cohort trends in housing debt and home equity. Paper presented at the annual conference of the Population Association of America, Philadelphia, PA.

Mirowsky, J., \& Ross, C. E. (1999). Economic hardship across the life course. American Sociological Review, 64, 548-569.

Muntaner, C., Eaton, W. W. Diala, C., Kessler, R. C., \& Sorlie, P. D. (1998). Social class, assets, organizational control and the prevalence of common groups of psychiatric disorders. Social Science and Medicine, 42, 2043-2053.

Murdock, S. H., Hamm, R. R., Potter, L. B., \& Albrecht, D. E. (1988). Demographic characteristics of rural residents in financial distress, social and community impacts of the farm crisis. In S. H. Murdock, \& F. L. Leistritz (Eds.), The farm financial crisis (pp. 113-140). Boulder, CO: Westview Press.

Pearlin, L., \& Schooler, C. (1978). The structure of coping. Journal of Health and Social Behavior, 19, $2-21$.

Peterson, C. L. (2004). Taming the sharks: Towards a cure for the high cost credit market. Akron, OH: University of Akron Press.

Prelec, D., \& Loewenstein, G. (1998). The red and the black: Mental accounting of savings and debts. Marketing Science, 17, 4-28.

Radloff, L. S. (1977). The CES-D scale: A self-report depression scale for research in the general population. Applied Psychological Measurement, 1, 385-401.

Schaninger, C. M., \& Buss, W. C. (1986). A longitudinal comparison of consumption and finance handling between happily married and divorced couples. Journal of Marriage and the Family, 48, 129-136.

Schor, J. B. (1998). The overspent American. New York: Basic Books.

Sherraden, M. (1991). Assets and the poor. Armonk, NY: M.E. Sharpe.

Smith, R. H., Diener, E., \& Wedell, D. H. (1989). Intrapersonal and social comparison determinants of happiness: A range-frequency analysis. Journal of Personality and Social Psychology, 56, 317 325.

Townsend, N. W. (2002). The package deal: Marriage, work, and fatherhood in men's lives. Philadelphia: Temple University Press.

US Courts (1997). Judicial business of the United States courts 1997. Retreived at http://www.uscourts.gov/judicial_business/f00sep97.pdf. Accessed 3 August 2005.

US Courts (1998). Judicial business of the United States courts 1998. Retreived at http://www.uscourts.gov/dirrpt98/f00sep98.pdf. Accessed 3 August 2005.

US Courts (2000). Judicial business of the United States courts 2000. Retreived at http://www.uscourts.gov/judbus2000/appendices/f00sep00.pdf. Accessed 3 August 2005. 
US Courts (2002). Judicial business of the United States courts 2002. Retreived at http://www.uscourts.gov/judbus2002/appendices/f00sep02.pdf. Accessed 3 August 2005.

US Courts (2004). Judicial business of the United States courts 2004. Retreived at http://www.uscourts.gov/judbus2004/appendices/f1.pdf. Accessed 3 August 2005.

US Department of Commerce (2005). Personal income and outlays: June 2005. Bureau of economic analysis news release, July (2005). Retrieved at http://www.bea.gov/bea/newsrelarchive/2005/ pi0605.pdf. Accessed 3 August 2005.

Vinokur, A. D., Price, R. H., \& Caplan, R. D. (1996). Hard times and hurtful partners: How financial strain affects depression and relationship satisfaction of unemployed persons and their spouses. Journal of Personality and Social Psychology, 71, 166-179.

Waite, L. J. (1995). Does marriage matter? Demography, 32, 483-507.

White, L., \& Rogers, S. J. (2000). Economic circumstances and family outcomes: A review of the 1990s. Journal of Marriage and the Family, 62, 1035-1051.

Xiao, J. J. (1996). Effects of family income and life cycle stages on financial asset ownership. Financial Counseling and Planning, 7, 21-30.

Xiao, J. J., \& Anderson, J. G. (1997). Hierarchical financial needs reflected by household financial asset shares. Journal of Family and Economic Issues, 18, 333-355.

Yadama, G. N., \& Sherraden, M. (1996). Effects of assets on attitudes and behaviors: Advanced test of a social policy proposal. Social Work Research, 20, 3-11. 